\title{
ResearchArticle
}

\section{Screening of acquired thermotolerant ragi [Eluesina coracana (L.) Gaertn] genotypes using T.I.R. technique}

\author{
B. Sujatha, P. Sirisha and Y.V. Bharathi
}

\section{SUMMARY}

For present population ragi is the major food as it is considered as the power house of health benefits. The production of ragi is coming down slowly due to the climatic factors like temperature and drought. Breeding of selected genotypes with increased thermotolerance is therefore, one of the most vital objective in crop improvement programme. Temperature induction response (TIR) technique has been developed to identify thermotolerant lines. 24 ragi genotypes has been tested using temperature induction response (TIR) technique. Ragi seedlings were exposed to gradual increase in temperature range of $32-48^{\circ} \mathrm{C}$ for $5 \mathrm{hrs}$ and later subjected to the lethal temperature of $54^{\circ} \mathrm{C}$ for $2 \mathrm{hrs}$. These treated seedlings were allowed to recover at $30^{\circ} \mathrm{C}$ and $60 \%$ relative humidity for 2 days. After recovery per cent survival, per cent reduction of root growth and per cent reduction of shoot growth was calculated. Among 24 ragi genotypes VR900, Indaf 8 and Udurumalliga were found resistant with low per cent reduction of root and shoot growth and the genotypes VR 1138 , CO-7 and OUAT- 2 were found susceptible with high per cent reduction of root and shoot growth. By using this TIR technique it is easy to identify thermotolerant lines from a large range of population at the seedling level itself

Key Words : Acquired thermotolerance, Temperature induction response, Lethal temperature

How to cite this article : Sujatha, B., Sirisha, P. and Bharathi, Y.V. (2018). Screening of acquired thermotolerant ragi [Eluesina coracana (L.) Gaertn] genotypes using T.I.R. technique. Internat. J. Plant Sci., 13 (1): 165-170, DOI: 10.15740/HAS/IJPS/13.1/165-170.

Article chronicle : Received : 16.11.2017; Revised : 05.12.2017; Accepted : 19.12.2017

\section{$\longrightarrow$ MEMBERS OF THE RESEARCH FORUM}

Author to be contacted :

B. Sujatha, Department of Botany, Andhra University, Visakhapatnam

(A.P.) India

Email : sudheer.ponnada@yahoo.com

Address of the Co-authors:

P. Sirisha, Department of Botany, Govt. Junior College, Gurla, Vizianagaram (A.P.) India

Y.V. Bharathi, Department of Botany, Government Degree College, Saluru, Vizianagaram (A.P.) India 